\title{
COVID-19'S INITIAL IMPACT ON FOOD SUPPLY CHAINS, RURAL MIGRANTS, AND POVERTY IN THE PEOPLE'S REPUBLIC OF CHINA
}

Shenggen Fan and Yumei Zhang

NO. 42

December 2021

\author{
ADB EAST ASIA \\ WORKING PAPER SERIES
}




\section{ADB East Asia Working Paper Series}

\section{COVID-19's Initial Impact on Food Supply Chains, Rural Migrants, and Poverty in the People's Republic of China}

Shenggen Fan and Yumei Zhang

No. 42 | December 2021
Shenggen Fan is Chair Professor at the College of Economics and Management and Dean of the Academy of Global Food Economics and Policy at China Agricultural University.

Yumei Zhang is Senior Research Fellow, Institute of Agricultural Economics and Development, Chinese Academy of Agricultural Sciences.

This paper was prepared as a background paper to Poverty, Vulnerability, and Fiscal Sustainability in the People's Republic of China under Asian Development Bank. 2015. Technical Assistance to the People's Republic of China for Promoting Partnerships for South-South Cooperation II. Manila (TA 8997-PRC). 
(C) 2021 Asian Development Bank

6 ADB Avenue, Mandaluyong City, 1550 Metro Manila, Philippines

Tel +632 8632 4444; Fax +63286362444

www.adb.org

Some rights reserved. Published in 2021.

Publication Stock No. WPS210464-2

DOI: http://dx.doi.org/10.22617/WPS210464-2

The views expressed in this publication are those of the authors and do not necessarily reflect the views and policies of the Asian Development Bank (ADB) or its Board of Governors or the governments they represent.

ADB does not guarantee the accuracy of the data included in this publication and accepts no responsibility for any consequence of their use. The mention of specific companies or products of manufacturers does not imply that they are endorsed or recommended by ADB in preference to others of a similar nature that are not mentioned.

By making any designation of or reference to a particular territory or geographic area, or by using the term "country" in this document, $A D B$ does not intend to make any judgments as to the legal or other status of any territory or area.

This work is available under the Creative Commons Attribution 3.0 IGO license (CC BY 3.0 IGO)

https://creativecommons.org/licenses/by/3.0/igo/. By using the content of this publication, you agree to be bound by the terms of this license. For attribution, translations, adaptations, and permissions, please read the provisions and terms of use at https://www.adb.org/terms-use\#openaccess.

This CC license does not apply to non-ADB copyright materials in this publication. If the material is attributed to another source, please contact the copyright owner or publisher of that source for permission to reproduce it. ADB cannot be held liable for any claims that arise as a result of your use of the material.

Please contact pubsmarketing@adb.org if you have questions or comments with respect to content, or if you wish to obtain copyright permission for your intended use that does not fall within these terms, or for permission to use the ADB logo.

Corrigenda to ADB publications may be found at http://www.adb.org/publications/corrigenda.

Notes:

In this publication, "\$" refers to United States dollars, and "CNY" refers to yuan.

ADB recognizes "China” as the People's Republic of China.

The ADB East Asia Working Paper Series is a forum for stimulating discussion and eliciting feedback on ongoing and recently completed research and policy studies undertaken by the East Asia Department of the Asian Development Bank (ADB) staff, consultants, or resource persons. The series deals with key economic and development problems, as well as conceptual, analytical, or methodological issues relating to project/program economic analysis, and statistical data and measurement. The series aims to enhance the knowledge on Asia's development and policy challenges; strengthen analytical rigor and quality of ADB's country partnership strategies, and its subregional and country operations; and improve the quality and availability of statistical data and development indicators for monitoring development effectiveness.

The ADB East Asia Working Paper Series is a quick-disseminating, informal publication whose titles could subsequently be revised for publication as articles in professional journals or chapters in books. The series is maintained by the East Asia Department. 


\section{CONTENTS}

TABLES AND FIGURES iv

ABSTRACT V v v v v v v v v v

ABBREVIATIONS vi vi vis

$\begin{array}{ll}\text { I. INTRODUCTION } & 1\end{array}$

II. IMPACT ON FOOD SUPPLY CHAINS, RURAL MIGRANTS, AND POVERTY 1

A. Food Supply Chains $\quad 1$

B. Agricultural Trade 2

C. Food Prices 3

D. Food Security and Nutrition 4

III. GROSS DOMESTIC PRODUCT AND EMPLOYMENT 4

IV. RURAL MIGRANT WORKERS

V. SMALL AND MEDIUM-SIZED ENTERPRISES

A. February 2020 Survey 9

B. May 2020 Survey 9

$\begin{array}{lr}\text { VI. POVERTY } & 9\end{array}$

$\begin{array}{ll}\text { VII. POLICY RESPONSES } & 12\end{array}$

VIII. LONG-TERM POVERTY REDUCTION STRATEGY 13

$\begin{array}{ll}\text { REFERENCES } & 15\end{array}$ 


\section{TABLES AND FIGURES}

\section{TABLES}

1 Consumer Price Index for Food Items in the People's Republic of China during the COVID-19 Outbreak, December 2019-June 2020

2 Economic Performance of the People's Republic of China during the COVID-19 Outbreak, January-June 2020

3 Civil Affairs Expense and Number of Guarantees of Subsistence Allowances

in the People's Republic of China during the COVID-19 Outbreak, 2019 and 2020

\section{FIGURES}

1 Consumer Price Index for Food Items in the People's Republic of China during the COVID-19 Outbreak (January $2019=100$ )

2 Distribution of Households with Migrants or Remittance Incomes in the People's Republic of China, by Income Quintiles

3 Cumulative Distributional Impacts of the COVID-19 on Remittance-Receiving Households' Total Incomes in the People's Republic of China under Three Simulation Phases

4 Poverty Impacts of the COVID-19 on Remittance-Receiving Households in the People's Republic of China under Three Simulation Phases

5 Impacts of the COVID-19 on Poverty Gap Index in the People's Republic of China under Three Simulation Phases 


\section{ABSTRACT}

The coronavirus disease (COVID-19) pandemic has had a profound effect on the economy of the People's Republic of China (PRC), ${ }^{*}$ especially on agriculture and food systems. The quick and forceful actions of the Government of the PRC in containing the virus have helped to control the pandemic and support economic recovery. In the meantime, the PRC has achieved its goal of ending absolute poverty in 2020 through various policies and investment programs, including the expansion of the coverage of subsistence allowance and unemployment benefits. The question now lies in how to sustain the elimination of absolute poverty, and how to make further progress to achieve various targets beyond income-based absolute poverty, especially in the areas of education, health, housing, rural and urban living conditions, and the environment.

First, productive sectors, including food and agriculture and its postproduction value chains, in rural areas must be revitalized. Rural education, health, and nutrition of rural residents, particularly of children and women, must be re-emphasized or prioritized. Policy should be redesigned to shift focus on the improvement of nutrition instead of grain sufficiency. Providing nutritious and healthy diets for children and women is an essential part of the overall development of human capital.

Second, special attention must be paid to rural migrants. Lack of unemployment protection and other social security insurance leaves migrants vulnerable to shocks. Because migrants predominately work for micro and small enterprises, government financial and policy support to these small businesses are important for mitigating the adverse income effects faced by migrants.

Third, an integrated rural and urban social security system, including unemployment insurance, is a more sustainable solution for building resilience among migrants, smallholder farmers, the urban poor, and other vulnerable groups.

Finally, strengthening rural-urban linkages, including physical, economic, social, and political connections, is crucial for revitalizing rural areas and ending poverty sustainably. Investment in rural infrastructure and in intermediate towns through quality rural and feeder roads, electricity, storage facilities, and communication and information technology can build connections and create hubs of economic activity that benefit smallholders and cities.

* This paper was prepared in August 2020, and the analysis presented here reflects the situation at that time. 


\section{ABBREVIATIONS}

$\begin{array}{ll}\text { CNY } & \text { yuan } \\ \text { COVID-19 } & \text { coronavirus disease } \\ \text { GDP } & \text { gross domestic product } \\ \text { NBS } & \text { National Bureau of Statistics } \\ \text { PRC } & \text { People's Republic of China } \\ \text { SMEs } & \text { small and medium-sized enterprises }\end{array}$




\section{INTRODUCTION}

The coronavirus disease (COVID-19) pandemic has had a profound impact on the economy of the People's Republic of China (PRC) and the people's day-to-day lives. Food supply chains were severely disrupted, rural migrants could not return to their urban posts, and poor consumers could not access healthy and nutritious foods because of lost income and increased prices of vegetables and animal-sourced proteins. Poor and low-income people have been particularly vulnerable to the shock. In 2019 before the outbreak, the PRC had 5.5 million poor people based on the official national poverty line, which is roughly equivalent to the World Bank's definition of extreme poverty of $\$ 1.90$ per day measured in 2011 purchasing power parity. Because of the pandemic, even some nonpoor populations, such as rural migrants and farmers producing fresh and live animal products, and urban workers in the services sector, may have fallen back into poverty.

In February 2021, the Government of the PRC officially announced that it had succeeded in ending absolute poverty in 2020 through various policies and investment programs including expansion of the coverage of subsistence allowance and unemployment benefits. While there is no doubt that this goal has been achieved, the challenges are (i) how to sustain the eradication of absolute poverty; and (ii) how to make further progress to achieve various targets beyond income-based absolute poverty such as in education, health, housing, rural and urban living conditions, and the environment. This brief synthesizes findings from various published sources, ad hoc reports, and seminar presentations. Although these findings are not from assessments and evaluations based on large, rigorously designed household surveys, they can provide useful, indicative insights on how the pandemic has affected food supply chains, food prices, employment of rural migrants, the rural and urban poor, and other vulnerable groups.

\section{IMPACT ON FOOD SUPPLY CHAINS, RURAL MIGRANTS, AND POVERTY}

Although the COVID-19 outbreak and the floods in southern parts of the country in June 2020 have slowed down the progress, the PRC managed to end absolute poverty in 2020 owing to the constant assessment of progress and identification of actions needed to achieve this target. Since January 2020, various government agencies, researchers, and other stakeholders have been monitoring and evaluating the performance and progress of poverty reduction in different locations amid the pandemic, particularly in designated poor counties, townships, and villages.

\section{A. Food Supply Chains}

The COVID-19 outbreak in the PRC began in December 2019 in Wuhan, Hubei Province, but the impact was not felt until 23 January 2020 when a lockdown was declared in Wuhan. This occurred just before the Chinese New Year. As is traditional, producers, processors, retailers, wholesalers, and even individual household families had stored food for at least 2 weeks prior to the lunar event. Thus, the immediate impact was small. However, as more provinces began to introduce lockdowns, physical distancing, and restrictions on the movement of people and food; and as the government closed communities (urban districts and rural villages and towns) and shut down nonessential economic activities (including transportation, construction, factories, restaurants, cinemas, and entertainment parks), the whole of 
February 2020 was the most difficult month in the PRC for people's livelihoods and economic activities (Fan, Si, and Zhang 2020).

Poultry supply was affected from the beginning of February 2020. Roadblocks disrupted feed supply, marketing of products, and the return of workers after the Chinese New Year holiday. The ban on the movement of live poultry prevented farmers from marketing chicken and eggs, which led producers to bury chicks and ducklings alive. According to industry estimates, the supply of live chicken and ducklings decreased by about 50\% in February (China Agricultural University 2020). According to the National Bureau of Statistics of China (NBS), the supply of meat, already affected by the extended impact of African swine fever, likewise plunged (NBS 2020a). COVID-19 affected farmers' purchases of seeds, fertilizers, pesticides, and other inputs in crop production. Seed supply was a major concern. The China Seed Association (2020) also reported that the outbreak adversely affected the production and operation of more than $90 \%$ of seed enterprises.

The supply chain as a whole, that is, the food system beyond agricultural and food production, was affected significantly. Within the whole supply chain, only $23 \%$ of agricultural products are directly consumed by households, while $77 \%$ are used as intermediate inputs, of which $41 \%$ go to food processing enterprises, and $3 \%$ are used by restaurants (Zhang et al. 2020a). In the wake of the COVID-19 outbreak, many orders were cancelled, and many restaurants had to close their doors. The supply of processed foods remained relatively abundant, but production was affected by a lack of workers and falling demand for agricultural products (Fan, Si, and Zhang 2020).

While agricultural activity is often excluded from mitigation policies (the green channels), the indirect effects of the mitigation effort on the agriculture sector are significant. Many agri-food processing industries were directly hit by lockdown policies, further affecting downstream agriculture and other components of the supply chain and food system.

A study by Min, Zhang, and Li (2020) on Wuhan, the epicenter of the virus in the PRC, also found that more than $80 \%$ of sample food suppliers had been negatively affected by COVID-19. The decrease in revenues of food suppliers because of the pandemic was affected by family size, household registration, number of COVID-19 patients in the local community, food categories that the suppliers sell, and food sources. The impact of the pandemic control measures on different stages of the food supply chain also varied significantly. E-commerce platforms played a more important role than the traditional supply chain in guaranteeing food supply in Wuhan. Although the control measures affected local food supply chains negatively, the effects were short term and were eliminated with relaxed control measures on food transportation.

\section{B. Agricultural Trade}

At the onset of COVID-19 outbreak, the PRC's agricultural exports plunged dramatically (Cao et al. 2020). According to the data from the General Administration of Customs, the PRC's exports decreased by $11.6 \%$ year-on-year in January and February 2020. Immediately following the outbreak, the agricultural export supply chain began to experience various short-term problems. Many firms producing export commodities remained closed as employees could not return to work, and some export companies reported a loss of more than $30 \%$ because of a lack of employees showing up to work (Cao et al. 2020). Additionally, transportation control increased shipping fees. A survey on agricultural export firms shows that $69.9 \%$ of the respondent firms experienced an increase in logistical fees (Cao et al. 2020).

Further, the operation efficiency of domestic ports declined, resulting in reduced transportation capacity. The operation of foreign ports is still not as efficient as in the past, with some countries even closing their ports, substantially affecting the normal unloading and customs clearance process. 
For example, as the pandemic worsened, the Queensland Maritime Safety Authority, where the port of Brisbane, Australia is located, banned all foreign merchant ships from docking ports in all Queensland regions for 14 days. In Europe, it was reported that, in view of the measures to seal cities, internal land transport logistics enterprises took a major hit: the highway connecting Germany and Poland became congested, which also affected the export of the PRC's agricultural products to those destination countries (Cao et al. 2020).

\section{Food Prices}

Prior to the outbreak, food prices in the PRC were already facing upward pressure. While the total consumer price index went up 4\% for the whole of 2020 (January $2019=100$ ), the food price index increased by $15.5 \%$ largely because of a meat price surge of $66 \%$, which in turn was caused by pork price escalation because of the impact of African swine fever (Figure 1).

The pandemic further increased food prices, particularly those of vegetables. Total consumer price index went up to 101.4 in January 2020 and further to 102.2 in February (December 2019 = 100). The food price index went up to 104.4 in January, largely because of the Chinese New Year. But the price index escalated further to 108.9 in February largely because of control measures. The price index for meat, which includes poultry, beef, pork, and mutton, increased by 14 percentage points between December 2019 and February 2020. Prices of vegetables increased the most, by 26.3 percentage points in January and February (Table 1). The impact on vegetables was rapid because of its short production cycle, and prices were affected as early as January 2020.

\section{Figure 1: Consumer Price Index for Food Items in the People's Republic of China during the COVID-19 Outbreak (January $2019=100$ )}

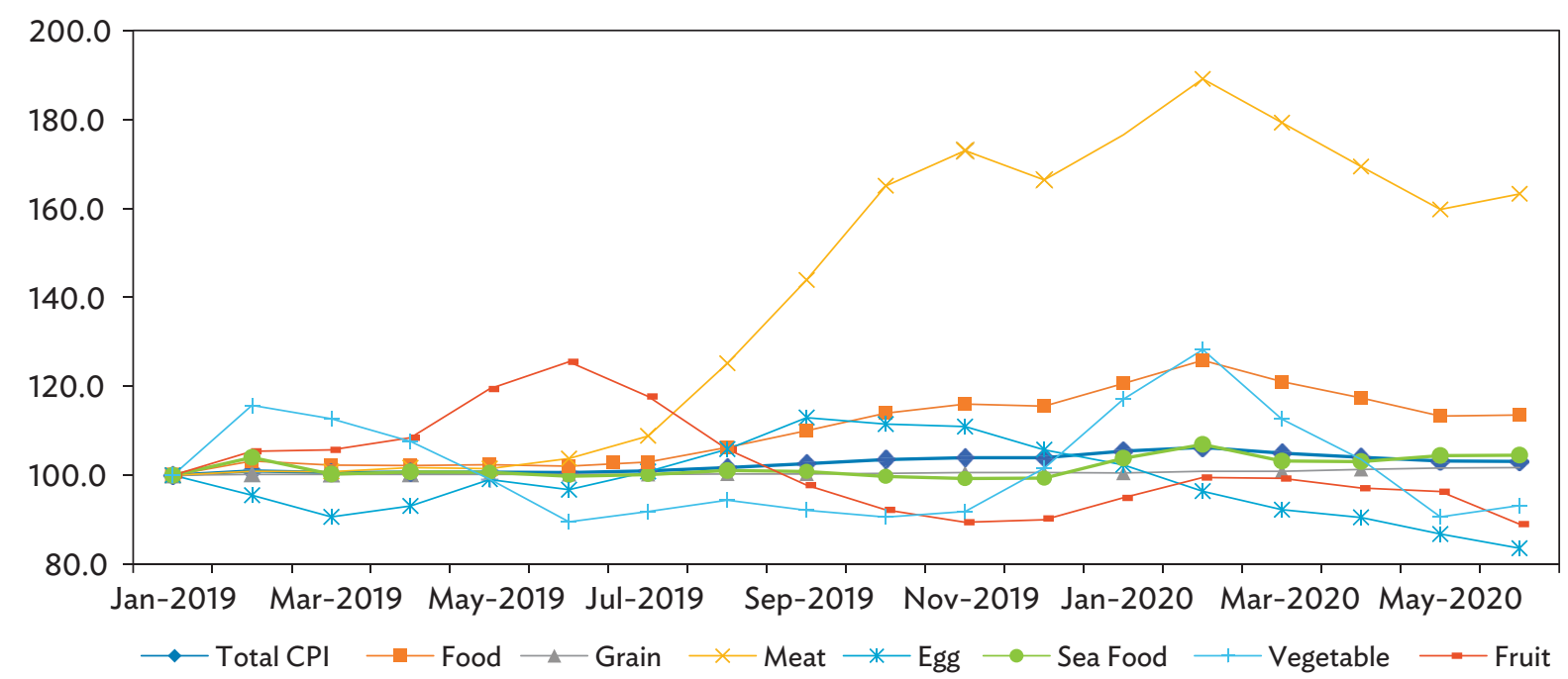

COVID-19 = coronavirus disease, $\mathrm{CPI}=$ consumer price index.

Source: National Bureau of Statistics. 2020a. National Data. http://data.stats.gov.cn/easyquery.htm? cn=A01 (accessed 12 July 2020). 
Table 1: Consumer Price Index for Food Items in the People's Republic of China during the COVID-19 Outbreak, December 2019-June 2020

\begin{tabular}{lcccccccc}
\hline & Total & Food & Grain & Meat & Egg & Seafood & Vegetable & Fruit \\
\hline December 2019 & 100.0 & 100.0 & 100.0 & 100.0 & 100.0 & 100.0 & 100.0 & 100.0 \\
January 2020 & 101.4 & 104.4 & 99.9 & 106.1 & 96.8 & 104.5 & 115.3 & 105.5 \\
February 2020 & 102.2 & 108.9 & 100.3 & 113.6 & 91.2 & 107.6 & 126.3 & 110.6 \\
March 2020 & 101.0 & 104.8 & 100.3 & 107.7 & 87.3 & 103.9 & 110.9 & 110.3 \\
April 2020 & 100.1 & 101.6 & 100.7 & 101.8 & 85.6 & 103.8 & 102.0 & 107.9 \\
May 2020 & 99.3 & 98.1 & 101.0 & 96.0 & 82.1 & 105.1 & 89.2 & 107.1 \\
June 2020 & 99.2 & 98.2 & 101.1 & 98.1 & 79.1 & 105.2 & 91.7 & 98.9 \\
\hline
\end{tabular}

COVID-19 = coronavirus disease.

Source: National Bureau of Statistics. 2020a. National Data. http://data.stats.gov.cn/easyquery.htm?cn=A01 (accessed 12 July 2020 ).

By March 2020, food prices had begun to level off. In fact, by June, most food prices had returned to pre-crisis levels. The total food price index was 1\% lower than that in December 2019 and prices of meat, eggs, vegetables, and fruits were all lower, with the only exception of seafood, which was still $5 \%$ higher.

\section{Food Security and Nutrition}

The PRC had enough food stock, particularly cereals (rice, wheat, and corn), as it had a bumper harvest in 2019 and reaped another good summer harvest (an increase of 0.9\%) as of July 2020. According to government sources, there were enough cereals in stock to feed the population for a whole year-one of the reasons why cereal prices had been stable. However, prices of meat and vegetables had increased in February, March, and June 2020, implying that concerted efforts are still needed to prevent any shortage of these foods in the future.

Because of the lost income and jobs, consumers had switched to less nutritious, cheap staple foods away from more expensive and nutritious foods such as fruits, vegetables, and animal-sourced proteins. Rozelle et al. (2020) found that majority of villagers have been reducing their spending on food, and people were buying more grains and staples in bulk at low cost in lieu of more expensive foods like meat and produce. This also indicates that nutrition declined-at least among a share of rural families. This is particularly concerning for families with young children, as research shows that nutritional deficiencies in early childhood can significantly inhibit cognitive development, which is linked to adverse outcomes in later life. These will have long-term negative impacts on the citizens' health. Children, women, and other vulnerable population groups need special attention when designing policies on food security and nutrition.

\section{GROSS DOMESTIC PRODUCT AND EMPLOYMENT}

The lockdown phase because of the pandemic and the associated mitigation measures significantly hit the economy, and the food system in particular. Official data from NBS showed that total gross domestic product (GDP) during the first quarter of 2020 declined by $6.8 \%$, with agriculture down by $3.2 \%$, industry by $9.6 \%$, and services by $5.2 \%$ (Table 2). In the second quarter of 2020 , the economy recovered rapidly, with GDP growth recovering to $3.2 \%$, led by industry at $4.4 \%$ year-on-year, and agriculture 
by $3.4 \%$ compared to the same period in 2019 . The value added of services increased by $1.9 \%$ in the second quarter of 2020 , although this varied by subsector. Some services sectors recovered, such as wholesale and retail whose value added increased by $1.2 \%$; and transport with $1.7 \%$ rise in value added. However, some services sectors still faced difficulties, like tourism, hotels, and restaurants. The value added of hotel and restaurants decreased by $18 \%$ in the second quarter of 2020 year-on-year. Overall GDP growth in the first half of 2020 was still negative, a drop of $1.6 \%$ compared to the same period in 2019. The economy recovered rapidly in the second half of the year; the GDP grew by $4.9 \%$ in the third quarter and 6.5\% in the fourth quarter, back to a pre-COVID-19 pandemic rate. As a result, the GDP grew by $2.3 \%$ in the whole year (NBS 2021a). The GDP growth was mainly driven by investment which contributed 2.2 percentage points, and exports which contributed 0.7 percentage points to GDP growth, while the final consumption decreased, leading to a decline of 0.5 percentage points of GDP growth. The full year sectoral GDP growth rate of agriculture was 3.1\%, industry $2.6 \%$, and services $2.1 \%$. The annual GDP growth of most sectors returned to positive, especially sectors such as software and information technology services grew by $16.9 \%$, and finance by $7 \%$. However, some sectors were still contracting, such as hotel and catering which dropped by $13.1 \%$, rent and business services declined by $5.5 \%$, and wholesale and retail decreased by $1.3 \%$.

The economic contraction affected employment demand directly. Zhang et al. (2020a) estimated that the negative shocks on employment from COVID-19 are significant. Total employment decreased by 175 million full-time jobs (about 23\%) in the first quarter or lockdown phase. Employment of full-time positions in manufacturing fell by 63.8 million, in services by 77 million, and in agriculture by 34.4 million. While some of the lost jobs will reappear when the economy starts to recover, the total number of jobs was estimated to have declined by 26.2 million in the second quarter of 2020 .

\section{Table 2: Economic Performance of the People's Republic of China during the COVID-19 Outbreak, January-June 2020}

(\%)

\begin{tabular}{|c|c|c|c|c|}
\hline Sector & Specific Impacts & $\begin{array}{l}\text { January- } \\
\text { March }\end{array}$ & $\begin{array}{l}\text { April- } \\
\text { June }\end{array}$ & $\begin{array}{l}\text { January- } \\
\text { June }\end{array}$ \\
\hline $\begin{array}{l}\text { Total gross } \\
\text { domestic product }\end{array}$ & & $(6.8)$ & 3.2 & $(1.6)$ \\
\hline Agriculture & $\begin{array}{l}\text { Direct effects on crop production and demand are } \\
\text { limited. Shocks on livestock are larger because of } \\
\text { insufficient feed and transportation blocks. }\end{array}$ & $(3.2)$ & 3.4 & 1.1 \\
\hline Mining & Lack of labor and market demand & $(1.7)$ & & $(1.1)$ \\
\hline Manufacturing & $\begin{array}{l}\text { Manufacturers of essential goods, such as health and } \\
\text { food supplies, have the green channel to move their } \\
\text { goods, but productivity is affected by intermediate input } \\
\text { supply logistic restrictions and labor shortages. }\end{array}$ & $(10.2)$ & 4.4 & $(2.5)$ \\
\hline Food processing & $\begin{array}{l}\text { Production is affected by the shortage of labor and } \\
\text { intermediate inputs. }\end{array}$ & (11.1) & & \\
\hline Textiles & $\begin{array}{l}\text { Production is affected because of labor shortages } \\
\text { domestically, and the reduction of export demand globally. }\end{array}$ & $(16.8)$ & & $(4.5)$ \\
\hline $\begin{array}{l}\text { Auto parts and } \\
\text { accessories }\end{array}$ & $\begin{array}{l}\text { Production is affected severely because of the lockdown } \\
\text { in Hubei, and less demand because of limited movement. }\end{array}$ & $(26.0)$ & & (3.1) \\
\hline Construction & $\begin{array}{l}\text { Affected by labor shortage and the supply of construction } \\
\text { materials }\end{array}$ & $(17.5)$ & 7.8 & (1.9) \\
\hline Utilities & $\begin{array}{l}\text { A decline in demand because of the shutdown of } \\
\text { transportation and closed factories }\end{array}$ & $(5.2)$ & & $(0.9)$ \\
\hline
\end{tabular}


Table 2 continued

\begin{tabular}{|c|c|c|c|c|}
\hline Sector & Specific Impacts & $\begin{array}{l}\text { January- } \\
\text { March }\end{array}$ & $\begin{array}{l}\text { April- } \\
\text { June }\end{array}$ & $\begin{array}{l}\text { January- } \\
\text { June }\end{array}$ \\
\hline Services & $\begin{array}{l}\text { Services are affected by social distancing measures, } \\
\text { quarantine, contracted demand, and labor shortage. }\end{array}$ & $(5.2)$ & 1.9 & $(1.6)$ \\
\hline $\begin{array}{l}\text { Wholesale } \\
\text { and retail }\end{array}$ & $\begin{array}{l}\text { Many markets and shops are shut down and some } \\
\text { businesses are operating online. }\end{array}$ & $(18.0)$ & 1.2 & $(8.1)$ \\
\hline $\begin{array}{l}\text { Hotels and } \\
\text { restaurants }\end{array}$ & $\begin{array}{l}\text { Many of these businesses closed when social distancing } \\
\text { measures were adopted. }\end{array}$ & $(35.0)$ & $(18.0)$ & $(26.8)$ \\
\hline Transport & $\begin{array}{l}\text { The domestic public transport is partially closed, and the } \\
\text { number of international flights was also reduced. }\end{array}$ & $(14.0)$ & 1.7 & $(5.6)$ \\
\hline Other services & Labor shortage and less demand for services & $(2.0)$ & $(0.9)$ & $(1.4)$ \\
\hline Migrant farmers & $\begin{array}{l}\text { Some migrant farmers had to stay in their hometowns } \\
\text { because of the quarantine. The migrants who returned } \\
\text { to work declined by } 30 \% \text { at the end of February } 2020 \text {, } \\
\text { and by }-2.7 \% \text { at the end of June. The average wage rate } \\
\text { decrease was } 6.7 \% \text { year-on-year. }\end{array}$ & Not available & & \\
\hline Exports & $\begin{array}{l}\text { Demand for exports dropped because of lack of labor and } \\
\text { cancellation of export orders. }\end{array}$ & $(11.4)$ & & $(6.2)$ \\
\hline
\end{tabular}

$($ ) = negative, COVID-19 = coronavirus disease.

Note: Values are percentage changes in value added or revenue in 2020 over the same period in 2019.

Source: National Bureau of Statistics. http://www.stats.gov.cn/tjsj/zxfb/202004/t20200417_1739327.html; http://data.stats.gov.cn/ easyquery.htm (accessed 12 July 2020).

Both unskilled and skilled labor employment have been affected significantly by COVID-19, but the simulations of Zhang et al. (2020a) show that the shocks for unskilled labor are larger than for skilled labor. More than 46 million full-time jobs in agriculture and the food supply chain, or about $27 \%$ of total employment, were lost in the lockdown phase, with the most significant job losses being in agri-food processing and services. Employment recovery was slower in agriculture and food than in other sectors because of the slower recovery of restaurants and related services. Aggregate employment (full-time jobs) in food and agriculture decreased by 8.6 million, and accounted for about $33 \%$ of total jobs lost. Only when the economy returns to normal with a resumption of export demand will more jobs be created in the agriculture and food sector.

\section{RURAL MIGRANT WORKERS}

Rural migrant workers are a vast, special, and vulnerable group, which is facing severe challenges and suffering the hardest shock as a result of the restrictive prevention and control policy measures during the early lockdown phase. There were 290.8 million rural migrant workers in 2019, of which 116.5 million worked within local counties and 174 million migrant workers worked in cities out of their hometown counties (NBS 2020c). The migrant workers decreased by $30.6 \%$ at the end of February 2020, as more than 53 million migrant workers were held up in their hometowns because of the lockdown policies. The migrant workers' average wage rate also declined by $7.9 \%$ in the first quarter of 2020 . Most of the migrant workers returned to the cities in the second quarter of 2020 , but the number of migrant workers was still less compared to the same period in 2019-a decrease of 2.7\% (about 4.7 million) as of the end of June 2020. Similar to the first quarter of 2020 , migrant workers' average wages dropped by $6.7 \%$ in the second quarter of 2020 (NBS 2020c). 
A more detailed and comprehensive household survey during the pandemic was not feasible. But the survey conducted by Beijing University's China Family Panel Studies in 2018 provides an important profile of rural migrants. The survey shows that $42 \%$ of households in 2018 either had migrants as family members or remittance recipients (Figure 2), and the share was much higher for rural households (54\%) than for urban households (30\%), as noted by Zhang et al. (2020b). Remittances sent by migrants back home are an important income source for millions of rural households, many of which live in remote and poor areas. Remittances account for about 30\% of total incomes for remittance-receiving households, according to the survey data.

As remittances are especially important in enabling many low-income rural households to stay out of poverty, the decline in remittances that resulted from the pandemic can have significant poverty effects. This was observed by Zhang et al. (2020b), who applied a micro simulation method to assess the impact of COVID-19 on migrants and remittance-receiving households' income using the 2018 China Family Panel Studies survey, with a particular focus on poor and low-income groups.

Most migrants work in the subsectors most exposed to the pandemic shock. According to a survey of migrant workers conducted by NBS in $2019,51 \%$ of migrant workers were engaged in the services industry, $6.9 \%$ of which are in hotel and catering, $6.9 \%$ in transport, and $18.7 \%$ in construction; while $27.4 \%$ are in the manufacturing industry (NBS 2020c). As expected, COVID-19 caused significant income losses for migrant workers, especially during the lockdown phase. About $70 \%$ of migrants were adversely affected because many migrant workers were employed in the subsectors that were affected the most; namely, construction, manufacturing, and hotel and catering. Moreover, most migrants work in micro and small enterprises as temporary and informal employees without formal employment contracts; thus, they were more vulnerable to the shock through loss of jobs and full incomes compared to urban formal sector workers.

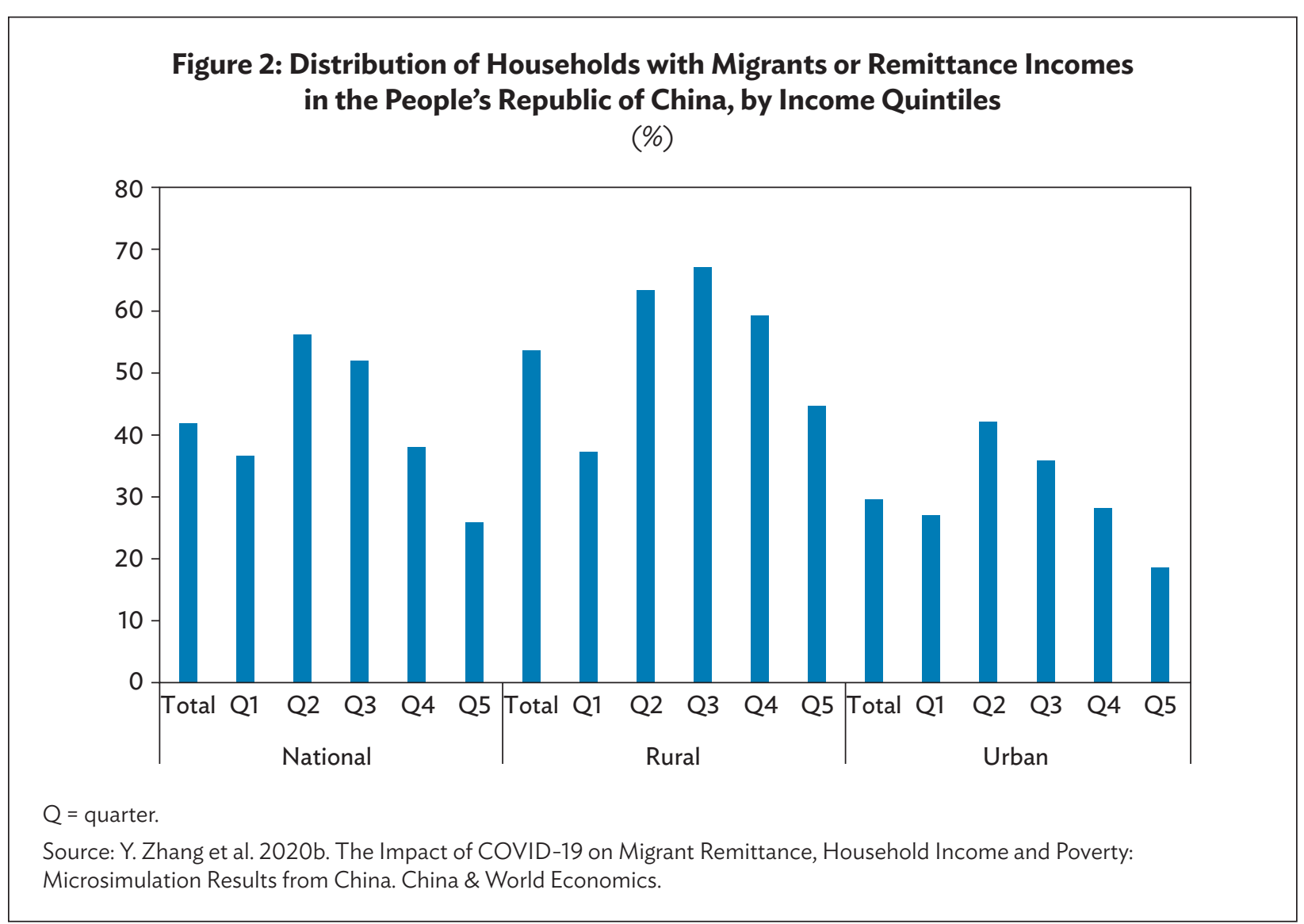


The impact on different migrant groups varied significantly. Rural migrants were affected more than their urban counterparts and migrants with low education were hit harder. As remittances are an important source of total income for remittance-receiving households, their total incomes fell sharply.

For households relying heavily on remittances, the declines in total incomes were significant during the lockdown phase, with income falling more than $40 \%$ for $5 \%$ of the households, more than $20 \%$ for $40 \%$ of the households, and at least $10 \%$ for $80 \%$ of the households (Figure 3 ).

The economic recovery would help many households regain lost income when their migrant family members started to return to work. However, income for many households remained below pre-pandemic levels. The simulations by (Zhang et al. 2020b) show that, even in the third phase with fast recovery, $20 \%$ households still have total income which is $10 \%$ lower than the base.

Figure 3: Cumulative Distributional Impacts of the COVID-19 on Remittance-Receiving Households' Total Incomes in the People's Republic of China under Three Simulation Phases

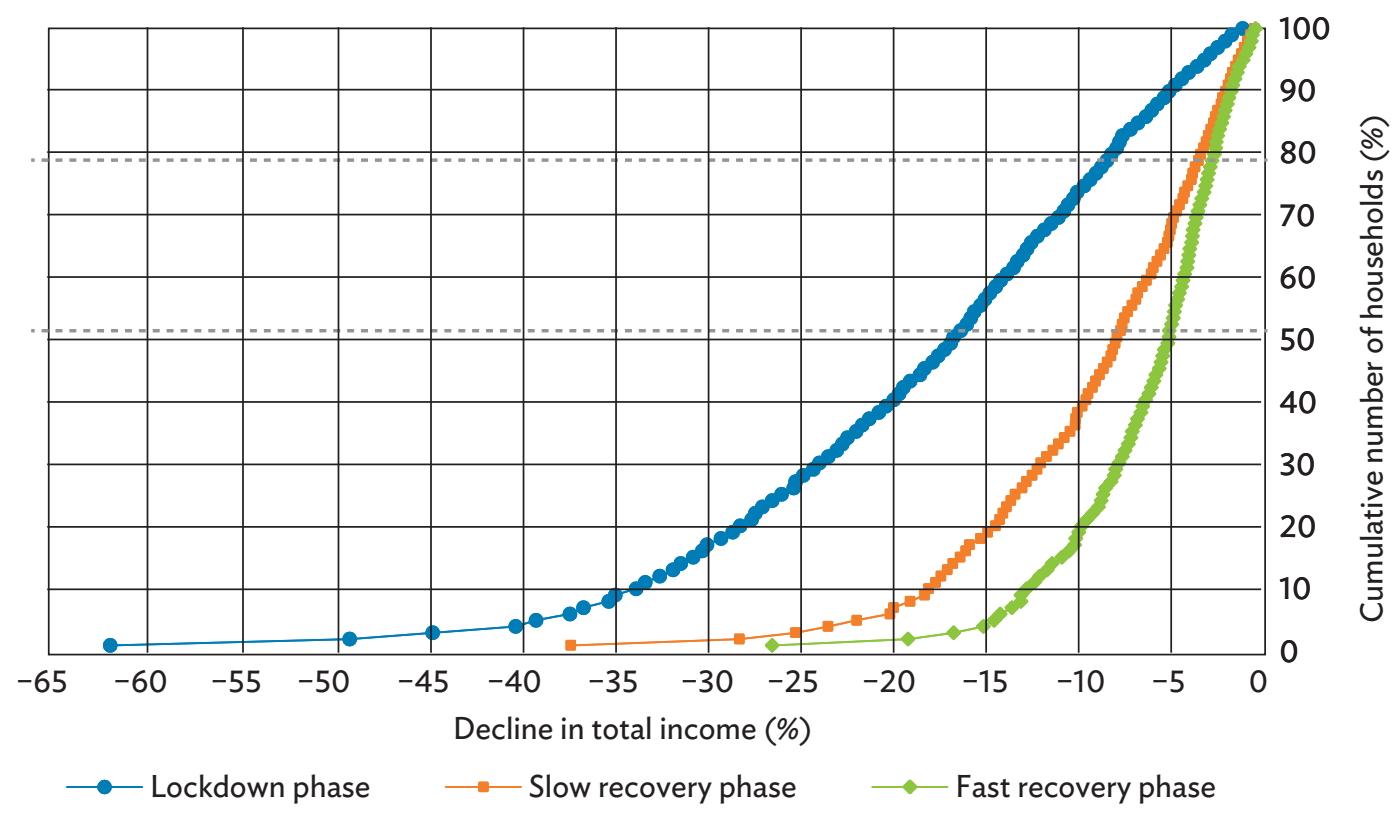

COVID-19 = coronavirus disease.

Note: Total affected remittance-receiving households $=100$.

Source: Y. Zhang et al. 2020b. The Impact of COVID-19 on Migrant Remittance, Household Income and Poverty: Microsimulation Results from China. China \& World Economics.

\section{SMALL AND MEDIUM-SIZED ENTERPRISES}

The Enterprise Survey for Innovation and Entrepreneurship in China at Peking University conducted two rounds of surveys in February 2020 and in May 2020 on the condition of micro, small, and medium-sized enterprises (SMEs) amidst the coronavirus outbreak. Dai, Hu, and Zhang (2020) listed the following effects on SMEs of COVID-19: 


\section{A. February 2020 Survey}

During the early stage of the outbreak, i.e., from late January to early February 2020, many SMEs, particularly those in food and agriculture, were severely affected. However, the impacts experienced by upstream and downstream firms were not identical, reflecting their different positions in the supply chain. While enterprises down the chain directly provide goods to consumers, upstream enterprises provide intermediate goods required by downstream actors. In general, upstream enterprises enjoy the advantage of large economies of scale. In contrast, downstream enterprises, including those in food and agriculture, consist mostly of labor-intensive, micro, small, and medium-sized firms. Upstream entrepreneurs hold different points of view regarding the impact of COVID-19, i.e., that the impact of the outbreak will be relatively small in the long run. The biggest issue for them is labor shortage. In contrast, downstream firms face more short-term issues, e.g., declining consumer demand as well as shortages of raw materials caused by disruptions in the supply chain. Like the upstream enterprises, they are experiencing shortages in the supply of labor too. Agriculture and food enterprises, which are usually downstream enterprises, have thus suffered disproportionately.

\section{B. May 2020 Survey}

The May 2020 survey found that agricultural enterprises had generally resumed work by mid-May, but most of them ran their production at partial capacity compared to their pre-pandemic level. Another important finding is that the major challenges have shifted from the supply side to the demand side. The May survey showed that the most mentioned challenge was lack of demand, with $53 \%$ of agricultural SMEs regarding this as a major issue.

The May survey also found that agricultural enterprises had a limited policy support from the government compared to nonagricultural enterprises. Also, despite the high demand for financial support, very few agricultural SMEs received it. About $64.5 \%$ of agricultural enterprises attached great importance to financial support such as low-interest loans or loan extensions. Yet, only about $12.2 \%$ of them reported to have received financial support. In general, agricultural enterprises faced greater working capital pressure because of their longer production cycle compared to nonagricultural enterprises. According to the May survey, the average ratio of inventory to cash flow was $35.9 \%$ for agricultural enterprises, compared to $32.7 \%$ for nonagricultural enterprises. Therefore, they had an urgent need for financial support to fare the shocks from COVID-19.

\section{POVERTY}

According to the NBS (2020d), household per capita income was CNY15,666 (about \$2,274) in the first half of 2020, with nominal growth rate of $2.4 \%$, but decreased by $1.3 \%$ in real price year-on-year. Rural household per capita real income decreased by $2 \%$ and urban household per capita real income decreased by $1 \%$ in the first half of 2020 compared to the same period in 2019. Absolute poverty elimination by the end of 2020 was one of the most important government tasks, and many measures were taken to increase poor people's income. The nominal rural household per capita disposable income increased by $5.5 \%-7.6 \%$ in some poor provinces, such as Guangxi, Guizhou, and Sichuan in the first half of 2020. The main driver for this was improved social security. For example, transfer incomes increased by $8.2 \%$; in particular, pensions increased by $9.3 \%$, and the social relief income increased by $13.2 \%$ (NBS 2020b). 
The rural poverty population had declined to 5.51 million and the poverty rate had decreased to $0.6 \%$ in 2019, according to the national rural poverty line of CNY2,300 at 2010 constant prices. However, the poverty rates of poor provinces remained above $1 \%$. The poverty rates of Gansu, Guizhou, Yunnan, and Qinghai provinces as well as Guangxi Zhuang Autonomous Region, Xizang Autonomous Region, ${ }^{1}$ and Xinjiang Uygur Autonomous Region were 1.0\%-2.2\%. There is no official poverty line for urban households.

The government always provides guarantees of subsistence allowances for poor and low-income urban households. The guarantee of subsistence allowances for rural residents started in 2007. In 2019, the residents who received subsistence allowances were 34.56 million (6.3\%) for rural areas and 8.61 million (1.0\%) for urban residents. In 2020, the civil affairs expense in the first 5 months increased by $15.6 \%$ to CNY145.7 billion from CNY126.0 billion during January-May 2019 (Table 3). Social assistance expenditure increased by $18.5 \%$ during the same period and reached CNY100.3 billion during January-May in 2020. Rural residents and rural households who received the guarantee of subsistence allowances increased by $2.4 \%$ in January 2020 and by 3.4\% in May 2020 year-on-year. However, both the number of urban residents and urban households that received subsistence allowances decreased $11.4 \%$ in May 2020 year-on-year.

Zhang et al. (2020b) used a higher relative poverty line, which is half of the median per capita income for the national total, or about CNY7,500 per year, and estimated the impact of COVID-19 on poverty of different population groups using data from a 2018 household survey conducted by Peking University. There are two reasons why a higher poverty line is used. First, the poverty rate was extremely low when the official national poverty line of absolute poverty (CNY2,300 based on 2010 prices) was used, which is equivalent to the $\$ 1.90$ World Bank extreme poverty line. Second, the PRC may consider raising its poverty line after 2020 when absolute poverty is eliminated. The CNY7,500 poverty line (equivalent to $\$ 4.9$ purchasing power parity [international dollars] per day) could be adequate to cover basic foods, education, health, and living conditions although the actual work in choosing a higher poverty line is still ongoing.

Table 3: Civil Affairs Expense and Number of Guarantees of Subsistence Allowances in the People's Republic of China during the COVID-19 Outbreak, 2019 and 2020

\begin{tabular}{lccc}
\hline & January-May 2020 & January-May 2019 & Change (\%) \\
\hline Civil affairs expense (CNY billion) & 145.7 & 126.0 & 15.6 \\
Social welfare expenditure (CNY billion) & 30.2 & 26.6 & 13.5 \\
Social assistance expenditure (CNY billion) & 100.3 & 84.6 & 18.5 \\
\hline Number of guarantees of subsistence & & & \\
$\quad$ allowances (million) & & & \\
Urban residents & 8.3 & 9.4 & $(11.4)$ \\
Urban households & 5.1 & 5.7 & $(11.4)$ \\
Rural residents & 35.4 & 34.6 & 2.4 \\
Rural households & 19.4 & 18.8 & 3.4 \\
\hline
\end{tabular}

() = negative, $\operatorname{COVID}-19$ = coronavirus disease.

Source: Ministry of Civil Affairs. http://www.mca.gov.cn/article/sj/.

Formerly known as Tibet Autonomous Region. 
Using the CNY7,500 poverty line, the poverty rate is higher among rural remittance-receivers at $21.4 \%$ than among urban remittance-receivers in the sample (11.4\%). Zhang et al. (2020b) found that falling remittances led to rising poverty, and an additional $4 \%$ of rural remittance-receiving households fell into poverty during the lockdown phase (Figure 4), comprising almost 3 million rural households with 9 million of their family members. Moreover, 1.3 million of these households were expected to stay in poverty persistently in 2020 even when the economy returned to normal.

Figure 4: Poverty Impacts of the COVID-19 on Remittance-Receiving Households in the People's Republic of China under Three Simulation Phases

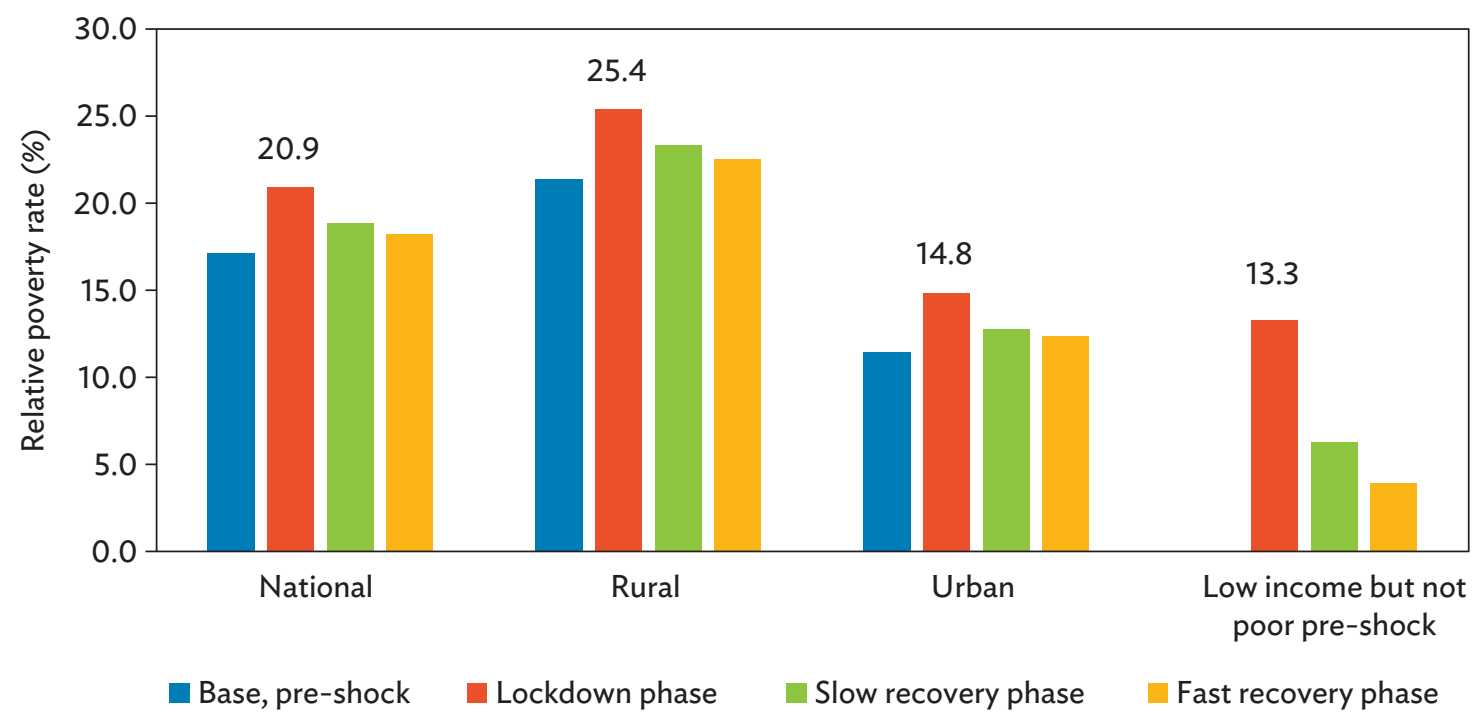

COVID-19 = coronavirus disease.

Source: Y. Zhang et al. 2020b. The Impact of COVID-19 on Migrant Remittance, Household Income and Poverty: Microsimulation Results from China. China \& World Economics.

COVID-19 also impacted urban poverty, with an additional 1.8 million urban households with 5.5 million family members newly becoming poor in the lockdown phase. This means that there were about 4.8 million rural and urban remittance-receiving households or 14.4 million family members in total who have fallen into poverty during the lockdown. Many pre-shock poor households became further impoverished, and the poverty gap index increased by more than 2 percentage points during the lockdown. Even with fast recovery and the economy almost returning to normal by the end of 2020, the poverty gap index has stayed at 0.4 percentage point lower compared to the base (Figure 5). 
Figure 5: Impacts of the COVID-19 on Poverty Gap Index in the People's Republic of China under Three Simulation Phases

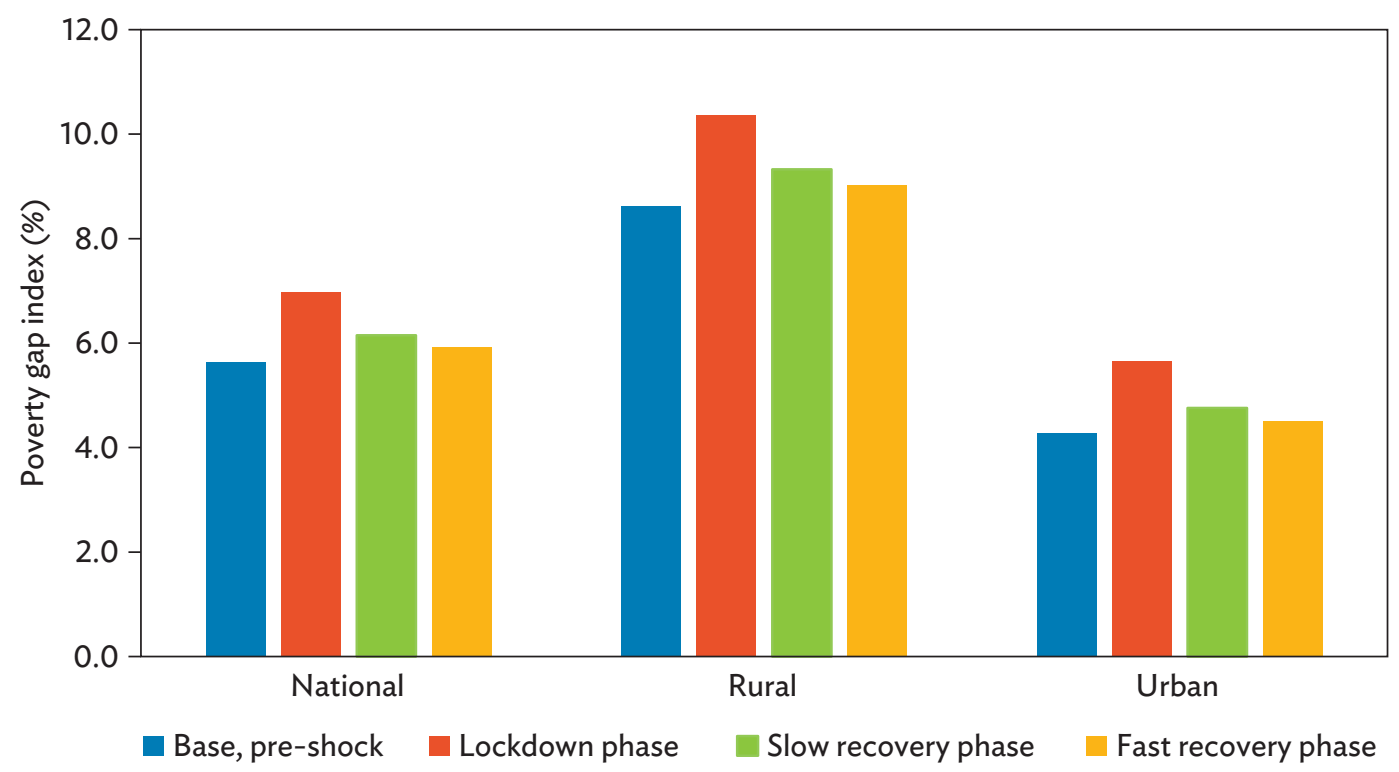

COVID-19 = coronavirus disease.

Source: Y. Zhang et al. 2020b. The Impact of COVID-19 on Migrant Remittance, Household Income and Poverty: Microsimulation Results from China. China \& World Economics.

\section{POLICY RESPONSES}

The Government of the PRC introduced numerous policies to mitigate the impact of the pandemic. A stimulus package was introduced to jump-start the economic recovery. Various tax concessions and subsidies or financial support were also launched targeting SMEs. Numerous municipalities issued consumption vouchers to stimulate local economies. Unemployment benefits and minimum allowance were raised, and their coverage was expanded.

In food and agriculture, various government policies, including green channels for transport of fresh foods and workers in the food sector helped minimize the impact of the shocks. In addition, financial support and tax concessions to farmers and agricultural enterprises, and online delivery platforms have played a critical role in ensuring the smooth functioning of the entire food supply chain. These are discussed in greater detail below.

On 30 January 2020, the Ministry of Agriculture and Rural Affairs, the Ministry of Transport, and the Ministry of Public Security jointly issued an Emergency Notice on Ensuring the Normal Circulation Order of "Food Basket" Products and Agricultural Production Materials, which strictly prohibited unauthorized interception, road breaks, and traffic disruption with respect to the transport of agricultural inputs and outputs, and ensured the normal flow of "food basket" products and agricultural input materials.

In early February 2020, Premier Li Keqiang called on ministries to coordinate and ensure an ample supply of food and effective logistics for delivering agricultural inputs, emphasizing the responsibility of local 
authorities. In the PRC, provincial governors are responsible for adequate grain supply, while city mayors are responsible for meat and vegetables. Feed production and slaughter enterprises were required to accelerate production to restore and increase the effective supply of livestock and poultry products. They were also being provided with production guidance and technical services to strengthen animal and plant epidemic prevention and control. All of these measures were to be implemented effectively and, as soon as possible, to avoid a hiccup in supply (Fan, Si, and Zhang 2020).

On 10 February 2020, the Ministry of Agriculture and Rural Affairs specified incentives for farmers to start farming (while observing necessary disease prevention and other measures) to support agricultural production. On 15 February 2020, in order to resume livestock production, the ministry and two other ministries jointly rolled out measures to support the reopening of feed and meat processing enterprises as soon as possible and to ensure the smooth delivery of raw materials and products. To encourage food imports and ease the pressure on food supply, the General Administration of Customs announced on 16 February 2020 that more countries and companies would be allowed to export agricultural and food products to the PRC. The administration also pledged to speed up customs clearance, shorten the quarantine and review period, and open green channels for agricultural products in key ports. The Ministry of Agriculture and Rural Affairs also published a plan for 2020 that outlined targets for crop planting areas and measures to ensure grain production and supply, improve plantation structure, and control chemical pesticide and fertilizer use in crop production (Fan, Si, and Zhang 2020).

\section{LONG-TERM POVERTY REDUCTION STRATEGY}

The PRC successfully managed its response to COVID-19 and is in a strong path to economic recovery. The GDP grew 18.3\% year-on-year in the first quarter of 2021(NBS 2021b). Ending poverty was not just a short-term goal for 2020, but should also be a key launch pad for long-term elimination of vulnerable population beyond income to include health, education, living conditions, and rural ecology and the environment. These are also key goals of rural revitalization.

First, productive sectors including food and agriculture and its postproduction value chains in rural areas must be revitalized. During the National People's Congress Conference, Premier Li announced a fiscal stimulus package of almost CNY3.6 trillion ( $\$ 506$ billion) to lead the PRC's economic recovery from the COVID-19 disruption (Fan 2020). The PRC has already planned to prioritize the development of agriculture and rural areas and to advance a batch of major projects to facilitate production and consumption according to the guidelines jointly issued by seven departments, including the Ministry of Agriculture and Rural Affairs (Xinhua 2020). Rural education, health, and nutrition of rural residents, particularly of children and women, must be re-emphasized or prioritized. Future human capital development, including education and health, is a foundation for achieving poverty reduction, improving well-being of rural residents, and modernizing rural areas in the long run. These investments include, first and foremost, improving primary and secondary education. Better educational systems have a strong positive impact on many indicators of human development, including incomes, wages, and labor productivity. Policy should also be redesigned to focus on the improvement of nutrition instead of grain sufficiency for rural residents. Providing nutritious and healthy diets for children and women is an essential part of the overall development of human capital.

Second, special attention must be paid to rural migrants. Lack of unemployment protection and other social security insurance leaves migrants vulnerable to shocks. Migrants were unlikely to cope with the unprecedented shock of COVID-19 by themselves, and would have needed help from the government. Many rural migrants could not return to their urban jobs because of closures or slowdown 
of manufacturing, construction, and services businesses. Unemployment benefits should be distributed to unemployed migrants and tap them to build rural roads, telecommunications, irrigation, and other productive assets. Part of the package could also be used to help returning migrants start new businesses to regenerate economic activities and employment in rural areas. Because migrants predominantly work for micro and small enterprises, government financial and policy supports to these small businesses are important for mitigating the adverse income effects faced by migrants.

Third, an integrated rural and urban social security system, including unemployment insurance, is a more sustainable solution for building resilience among migrants, smallholder farmers, the urban poor, and other vulnerable groups. These safety nets, which could be in the form of cash or in-kind transfers (context-specificity is important), should be accompanied by efforts to improve health and nutrition of vulnerable populations to protect them from diseases such as COVID-19 because nutritional level and mortality rates are intricately linked. Social safety nets are also crucial in the post-COVID-19 pandemic period to drive "reconstruction" efforts.

Finally, strengthening rural-urban linkages, including physical, economic, social, and political connections, is crucial for revitalizing rural areas and ending poverty sustainably in both rural and urban areas. Urban growth increases food demand and spurs dietary changes in urban areas. In turn, new demand can create opportunities for rural producers to improve their livelihoods. Broken value chains and poor coordination weaken rural-urban links and hold back progress on food security and nutrition. Investment in rural infrastructure and in intermediate towns-quality rural and feeder roads, electricity, storage facilities, and information and communication technology-can build connections and create hubs of economic activity that benefit smallholders and cities. 


\section{REFERENCES}

Cao, L. et al. 2020. Impact of COVID-19 on China's Agricultural Trade. China Agricultural Economic Review. 13 (1), pp. 1-21. https://doi.org/10.1108/CAER-05-2020-0079.

China Agricultural University. 2020. China Agricultural University Agricultural Enterprise Surveys. Beijing. China Seed Association. 2020. Questionnaire Survey and Analysis of the Impact of the COVID-19 on Seed Companies. http://www.seedchina.com.cn/.

Dai, R., J. Hu, and X. Zhang. 2020. The Impact of Coronavirus on China's SMEs: Findings from the Enterprise Survey for Innovation and Entrepreneurship in China. ERENET Profile. 15 (1), pp. 9-16. http://www.erenet.org/publications/profile51.pdf.

Fan, S. 2020. Despite challenges, China will end poverty. China Daily. http://www.chinadaily.com. cn/a/202006/22/WS5eeff442a310834817254761.html. 22 June.

Fan, S., W. Si, and W. Zhang. 2020. How to Prevent a Global Food and Nutrition Security Crisis under COVID-19? China Agricultural Economic Review. 12, pp. 471-480. 3 June

Min, S., X. Zhang, and G. Li. 2020. A Snapshot of Food Supply Chain in Wuhan under the COVID-19 Pandemic. China Agricultural Economic Review, 12 (4), pp. 689-704.

National Bureau of Statistics of China. 2020a. National Data. http://data.stats.gov.cn/easyquery. htm?cn=A01 (accessed 12 July 2020).

2020b. National Economy Continued to Recover in the First Half of 2020. http://www.stats.gov. cn/tjsj/zxfb/202007/t20200716_1776194.html.

_.2020c. 2019 National Migrant Survey Report. http://www.stats.gov.cn/tjsj/zxfb/202004/ t20200430_1742724.html.

_.2020d. Preliminary Results of Gross Domestic Product (GDP) for the First Quarter of 2020. http://www.stats.gov.cn/tjsj/zxfb/202004/t20200417_1739602.html.

2021a. Statistical Communiqué of the People's Republic of China on the 2020 National Economic and Social Development. http://www.stats.gov.cn/english./PressRelease/202102/t20210228_1814177.html.

_.2021b. National Economy Made a Good Start in the First Quarter. http://www.stats.gov.cn/ english/PressRelease/202104/t20210416_1816315.html.

Rozelle, S. et al. 2020. Lockdowns are Protecting China's Rural Families from COVID-19, but the Economic Burden is Heavy. Washington, DC: International Food Policy Research Institute. https://www.ifpri.org/ blog/lockdowns-are-protecting-chinas-rural-families-covid-19-economic-burden-heavy.

Xinhua. 2020. China to scale up investment in agriculture, rural areas. http://english.www.gov.cn/ statecouncil/ministries/202007/13/content_WS5f0c187ac6d06c4091250dc1.html. 13 July 2020.

Zhang, Y. et al. 2020a. Impact of COVID-19 on China's Macroeconomy and Agri-Food System-An Economy-wide Multiplier Model Analysis. China Agricultural Economic Review. 12 (3), pp. 387-407.

2020b. The Impact of COVID-19 on Migrant Remittance, Household Income and Poverty: Microsimulation Results from China. China \& World Economics. Under review. 


\section{COVID-19's Initial Impact on Food Supply Chains, Rural Migrants, and Poverty in the People's Republic of China}

This paper provides insights on how the coronavirus disease (COVID-19) pandemic has affected food supply chains, food prices, rural migrant workers, the rural and urban poor, and other vulnerable groups in the People's Republic of China (PRC). It proposes policy recommendations on sustaining the elimination of absolute poverty in the PRC. The paper also discusses ways of making further progress in the areas of education, health, housing, rural and urban living conditions, and the environment.

\section{About the Asian Development Bank}

ADB is committed to achieving a prosperous, inclusive, resilient, and sustainable Asia and the Pacific, while sustaining its efforts to eradicate extreme poverty. Established in 1966, it is owned by 68 members -49 from the region. Its main instruments for helping its developing member countries are policy dialogue, loans, equity investments, guarantees, grants, and technical assistance. 